\title{
ポリマー水溶液の多孔質媒体内流動における振動効果の解析
}

\author{
田中舘忠夫*・オマール・アブデルカリム ${ }^{* *} ・ 山$ 山崎 豊彦**
}

(平成 3 年 5 月 29 日受付, 4 年 1 月 29 日受理)

\section{Quantitative Analysis of Density Vibration of Polymer Solution Flowing through Porous Media}

By

Tadao TANAKADATE, Omar ABDELKARIM and Toyohiko YAMAZAKI

\begin{abstract}
In this paper, vibration theory of elastic body is applied as an analogy to the quantitative analysis of resistance factor of polymer solution measured when it flows through porous media.

Resistance against flow of polymer solution through porous media is not caused only by viscosity of polymer solution, but also affected by the energy dissipation by experiencing rarefaction and compression of polymer solution while flowing alternately in the throat connecting pores and in the open pore spaces. Euler Equation is modified to express such elastic resistance of polymer solution caused by the oscillation of normal stress in the fluid. Flow equation comprised of both Euler Equation and Darcy Equation is introduced to calculate both elastic and viscous resistances against flow through porous media. New equation is applied successfully to demonstrate the dilatant flow behavior of polymer solution in the flooding experiences through a capillary tube packed by glass beads and through Berea sand cores.

Diffusion equation modified to express the vibration effect of viscoelastic fluid is applied to solve the pressure loss of polymer solution flowing through porous media. Quantitative analysis of the resistance factor of flow of polymer solution through porous media is presented by the use of analytical solution of diffusion equation.
\end{abstract}

\section{1. 緒言}

前報1)では，ポリマー水溶液が多孔質媒体内を流動す る場合の流動抵抗として，ポリマー水溶液の粘度による 摩擦抵抗の他に，流路の断面積が変わることに起因する 弾性抵抗が新たに加わることを指摘した。そこでは, 流 動方向にかかる垂直応力の振動に起因する弾性抵抗を， 管径の異なる毛細管をつないだ流路内定常流動，および ガラスビーズを詰めた毛細管内定常流動の圧力損失につ いて定量的に計算した。本論文ではひき続きポリマー

* 住友石油開発株式会社

** 早稻曰大学 理工学部

Copyright (C) 1992, JAPT
水溶液をガラスビーズを詰めた毛細管，およびベレア仯 岩コアを通した場合の非定常流動について, 拡散方程式 を用いて定量的に解析することを試みた。

ポリマー水溶液がガラスビーズを詰めた毛細管や岩石 コアの上うな多孔質媒体内を流動する時洨，孔隙径の大 きな部分 (孔隙空間) と孔隙空間をつなぐ径の小さい部 分（ストロート）を連続して流れるため，水溶液は膨脹 と圧縮を繰り返し, 前報1)でも述べた通り, 流速す密度 あ周期的な变化を受ける。流速が大きい場合には，ボリ マ一水溶液は水や油等の压縮率の小さい流体と異なって 大きな圧縮性を持つ弾性体としての性質を現すため,こ の周期的变化を受けて弾性振動をすることになる。ポリ マー氷溶液が多孔質媒体内を流れる時に, 孔隙空間部分 やスロート部分において受ける密度の振動は，あたかも 
弾性波の振動と同様の現象として近似できる。外的な衝 撃による密度流としての弾性波が, 媒体を構成する分子 を振動させて擾乱することによって熱エネルギーを失っ て減衰する過程は, ポリマー水溶液が振動流として失っ ていく弾性エネルギーの損失に対応している。従って, 弾性波の振動理論の類推から,この上うな弾性流体の多 孔質媒体内の圧力損失を解析することは有効であると考 えられる。

ポリマー水溶液の弾性流体としての挙動にとって最る 重要な要素として, 弾性挙動に特徽的な時間遅れを表す 緩和時間は次式で与えられる1。

$$
\lambda=\frac{\mu_{0} C_{t}}{\alpha}
$$

ここで， $\lambda$ は緩和時間， $\mu_{0}$ と $C_{t}$ とそれぞれ流体のゼ口 シェア粘度と複合珐縮率を示す。 $\alpha$ は流体の剛性率と圧 縮膟の関係を表す比例定数である。

これまで,このようなポリマー水溶液の弾性体として の挙動について，毛細管内流動のような流路径の一定な 媒体の中での圧力損失, 粘度変化については数多くの研 究が行われたが, 本研究の対象となっているような多孔 質媒体内流動に関する研究は限られている。前報では, ポリマー水溶液の多孔質媒体内の定常流動について, 比 較的簡単な流路变化モデルによる垂直応力之密度変化 の関係を使った数值解析を試みてきたが，本報ではこ れまでの成果を基礎として弾性体の振動理論との類推 から应散方程式の非定常流解析解を求める方法で解析し た。

\section{2. ポリマー水溶液の振動流}

ポリマー水溶液をガラスビーズを詰めた毛細管，ある いは岩石コアのような多孔質媒体内に流す時, 溶液の通 る流路はガラスビーズや岩石を構成する砂岩粒子の大き さによって規定される。つまり，孔隙半径，あるいは孔 隙間スロートの広さによって決定される。いま，ガラス ビーズや砂岩粒子を半径 $r$ を持つ球によって近似し，多 孔質媒体が Fig. 1(a)に示すように，この球を正方充 填して作られていると仮定して孔隙間流路の断面䅣の変 化を求めてみる。流机の方向を $x$ 軸の正方向にとり, この流路断面積の変化を求める之次式の上うに表され る。

$$
S=(4-\pi) r^{2}+\pi(2 m r-x)^{2}
$$

ただし， $m$ は正方充填されている粒子の入口からの 個数である。流路の断面積 $S$ は, $m$ が奇数, 即古 $x=(2 n-1) r$ および $x=(2 n+1) r$ のとき, 最大值 $S_{\max }=$ $4 r^{2}$ となる。また, $m$ が偶数, 即ち $x=2 n r$ のとき, 最小值 $S_{\min }=(4-\pi) r^{2}$ となる。この関数の様子は
Fig. 1(b) に示す通りである。Fig. 1(b) からもわかる ように，このようにして求められる孔隙流路の断面積の 変化は波形になっているため,この流路を通って流れる ポリマー水溶液屯必然的にこの形状に沿って波動しなが ら流れる。（2）式で与えられる流動径路は，孔隙空間の 最大面積をとる点で微分不可能であり, 今後の数学的取 り扱いが不便であるため, Fig. 1(b) に点線で示すよう な正弦曲線によって近似すると, $\mathrm{x}$ 軸上の断面積の変化 は次式で与えられる。

$$
S=\pi r^{2} \sin \left(\frac{\pi x}{d}\right)+S_{\min }
$$

ここで $d$ はガラスビーズ，あるいは砂岩粒子の直径 $(=2 r)$ を表す。この連続関数による近似によっても最 大, 最小断面積は变わらず，これらの点における流速は 変わらない。

このようにして与えられる流動経路を通じて，一定体 積流量 $q$ を与えると, ポリマー水溶液がこの流路の孔 隙空間加ら孔隙空間までの一波長を流れるのに要する周 期 $\tau$ と角速度 $\omega$ が次のように求まる。

$$
\tau=\frac{d^{3}}{2 q}
$$

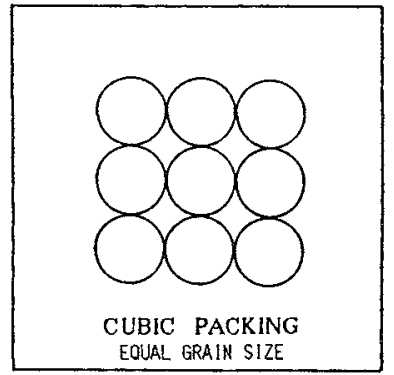

Fig. 1(a) Porous-media model.

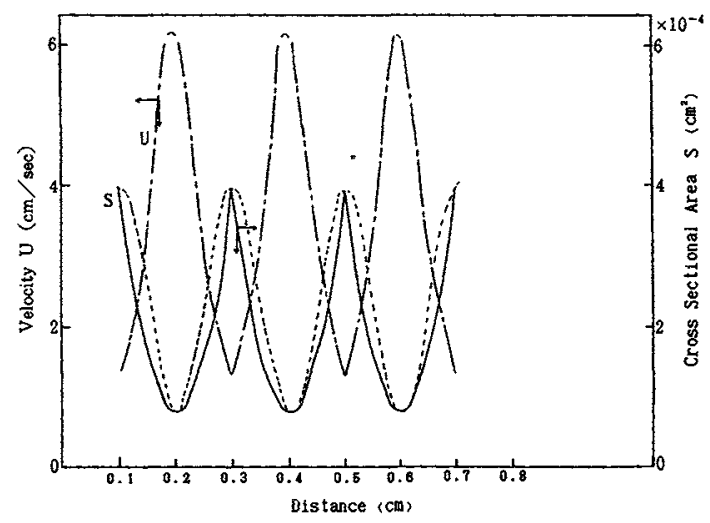

Fig. 1(b) Velocity oscillation through porous media. 


$$
\omega=\frac{4 \pi q}{d^{3}}
$$

角速度は流量 $q$ に比例し, ガラスビーズあるいは砂岩 粒子の直径の 3 乗に反比例することがわかる。

ここで, ガラスビーズを詰めた毛細管や岩石コア全体 中を流れるポリマー水溶液の流量 $Q$ と（5）式で使った ひとつの孔隙空間を流れる流量 $q$ との関係は, 毛細管 や岩石コアの断面に含まれるガラスビーズ，あるいは砂 岩粒子の数之同数の孔隙空間が含まれるものとして次式 で与えられる。

$$
q=\frac{d^{2} Q}{A}=d^{2} U_{D}
$$

ただし，A は毛細管，あるいは岩石コアの断面積を表 す。 $U_{D}$ はコア内流動時のダルシー流速とする。

（6）式を(5) 式に代入すると, 最終的に角速度が次の ように与えられる。

$$
\omega=\frac{4 \pi Q}{d A}
$$

\section{3. ポリマー水溶液流動解析のための拡散方程式}

弾性振動をする流体の流れは，オイラーの運動方程式, 流体の連続の式，および流体の状態の式を組み合わせる と波動方程式として表される。こうして導かれる波動方 程式は，弾性波や音波の伝憣を表す波動方程式と同じで， 一次元の系では一般に次のように表される。

$$
\frac{\partial^{2} \rho^{\prime}}{\partial x^{2}}=\frac{1}{V^{2}} \frac{\partial^{2} \rho^{\prime}}{\partial t^{2}}
$$

ここで, $\rho^{\prime}$ は弾性体の密度変化, $V$ は弾性波の伝幡速 度を表している。

弾性波や音波の伝幡速度 $V$ は, 媒体の密度変化が波 動として伝わる速さを表しており，弾性体としての媒体 そのものは動かない。これに対し，汭りマー水溶液の多 孔質媒体内流動では，弾性体としての水溶液が流れるこ とによって，多孔質流路にそって密度振動を生ずる。こ の場合の密度振動も平均流速加らの流速变動も（8）式を 満たす挙動をすることが予想される。但し，この場合は 弾性波の振動と異なって, 流速変化と密度変化は, 位相 を半周期ずらした反比例関係にあることが分かる。ポり マ一水溶液の圧縮率 $C$ は, 圧力变化に対する密度変化 の関係から次のように定義される。

$$
\rho=\rho_{0} \exp (C \Delta P)
$$

但し， $\rho_{0}$ は基準圧力 $P_{0}$ における流体密度を， $\Delta P$ は基 準圧力との差 $\left(P-P_{0}\right)$ を表す。

この関係から，流体が多孔質媒体を流れるとき，第 2 節に述べた通り，流路の断面積の変化に伴って流速が変
化することにより，死力む振動していることになる。特 に, 孔擦空間と孔隙空間を結ぶスロート部分では流速が 極めて大きくなるた，その部分の圧力ポテンシャルは 極めて小さくなり，流体密度も（9）式に徤って小さくな る。即ち, 弾性波の振動と同じように多孔質媒体中を流 れる流体では, 運動エネルギーと玨力で代表されるポテ ンシャル・エネルギーが交互に入れ代わりながら流動す ることになる。

特にポリマー水溶液のように弾性の大きい流体が多孔 質媒体内を流動するときに考慮にいれなければならない ことは, 弾性流体が孔隙空間と孔隙空間の間のスロート の部分で，このような激しい流速変化，あるいは密度变 化を受けるときに生ずる応力緩和現象がある。流路が急 激に狭まって流速が極めて大きくなるとき, 密度変化が 即座に対応できないためずれ遅れが起って瞬間的に極低 密度状態が生まれ，これを通常の密度状態に戻すまでの 間に弾性エネルギーの損失が起こる。既に, 前報1)で導 入した通り，この緩和時間の存在によって起こる瞬間的 密度低下は，瞬間的に見掛けの圧縮率が大きくなるかの ような現象として，動的圧縮率，あるいは時間圧縮率 $C_{i}$ 亡呼ばれる新しい特性係数の導入によって表され る。これに対して，これまで(9)式で扱ってきた王縮率 $C$ は静的圧縮率と呼ばれるものである。このふたつの圧 縮率の入れ代わる関係は, 振動の角速度 $\omega$ と弾性流体の 緩和時間 $\lambda$ の関数として次のように表される。但し，こ こでは前報で用いたずり速度の代わりに，多孔質媒体の ような連続した振動流に適用するために，ふたつの圧縮 率の入れ代わりを判断するパラメーターとして，振動流 の角速度

$$
C_{t}=C \frac{1+\omega^{2} \lambda^{2}\left(C_{i} / C\right)^{2}}{1+\omega^{2} \lambda^{2}\left(C_{i} / C\right)}
$$

（10）式右辺の因子となっている角速度 $\omega$ と緩和時間 $\lambda の$ 積 $\omega \lambda$ は, 周期 $\tau$ を用いて書き直すと $2 \pi \lambda / \tau$ と表 され，この項が緩和時間と密度振動の周期との比になっ ていることがわかる。即ち，緩和時間が振動の周期を越 える亡き, $\omega \lambda>1$ の状態が生まれ，動的王縮率が大き く影響して複合圧縮率 $C_{t}$ を上げることがわかる。逆に, 緩和時間が周期に比べて充分小さいとき， $\omega \lambda \fallingdotseq 0$ とな り, 複合圧縮率は常に静的厈縮率と等しくなる。従って, 水や油のように非弾性とみなせる流体では複合生縮率の 概念を使う必要はないことになる。

この新たな複合任縮率 $C_{t}$ を導入すると，弾性流体の 持つ緩和特性によって, 孔腺空間と孔隙空間をつなぐス ロートの部分で, 静的压縮率の值から得られるより急激 な圧力降下が生じる1)。この余剩圧力降下は，(10）式か ら明らかな通り，流速が大きく，さらに緩和時間が長い 
ほど大きくなる。この弾性流体の持つ応力緩和現象によ り, 流体の弹性エネルギーの損失およびそれによる圧力 損失が起こる。

一方, 非常に小さな圧縮率を持つ粘性流体の多孔質媒 体内流動は，運動方程式としてオイラーの式の代わりに ダルシーの式を使って, 連続の式, 状態の式と組み合わ せた拡散方程式によって次のように表される。

$$
\frac{\partial^{2} P}{\partial x^{2}}=\frac{1}{D_{f}} \frac{\partial P}{\partial t}
$$

ここで, $D_{f}$ は搪散係数を表し，多孔質媒体の場合は次 の式で与えられる。

$$
D_{f}=\frac{K}{\phi \mu C}
$$

$K$ は浸透率， $\phi$ は孔隙率を表す。

粘弾性流体に対しては，（8）式と（11）式の両式が同 時に適用される。従って, 粘弾性流体に用いる運動の式 は，オイラーの式とダルシーの式を併せた次の形をとる。

$$
\frac{\partial P}{\partial x}=-\left(\frac{\mu}{K}+\rho \frac{\partial U}{\partial x}\right) U_{D}
$$

多孔質媒体内における流速 $U$ の変化は, ガラスビー ズあるいは砂岩䊀子の間を通る孔隙空間之孔隙空間を 結ぶ流路の形状によって規制されるため, 右辺第 2 項の 流速の流動方向での公配は，ガラスビーズ，あるいは砂 岩粒子の球径 $d$ を用いて次のように与えられる。

$$
\frac{\partial U}{\partial x}=-\frac{4 q}{d^{3}} \frac{\partial d}{\partial x}
$$

従って，(13）式は次のようになる。

$$
\frac{\partial P}{\partial x}=-\left(\frac{\mu}{K}-\frac{4 \rho q}{d^{3}} \cdot \frac{\partial d}{\partial x}\right) U_{D}
$$

（12）式内の易動度 $K / \mu$ を新たに次のように定義すれ ば，(15) 式はダルシーの式と同形にとり扱えるように

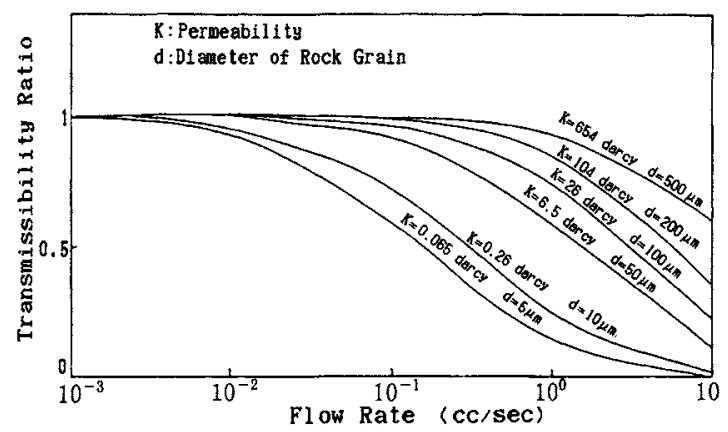

Fig. 2 Effect of energy dissipation by velocity oscillation on transmissibility of polymer solution through porous media.
なる。

$$
\frac{\mu^{\prime}}{K^{\prime}} \equiv \frac{\mu}{K}-\frac{4 \rho q}{d^{3}} \frac{\partial d}{\partial x}
$$

(16) 式の関係を使って, 流体の振動に伴う弾性エネル ギーの損失によって, 多孔質媒体内を流れる流動抵抗が どのように変化するかをプロットしたのが Fig. 2 であ る。Fig. 2 の縱軸は易動度比 $\left(K^{\prime} / \mu^{\prime}\right) /(K / \mu)$ を表 している。この図から，新たに定義した易動度 $K^{\prime} / \mu^{\prime}$ が流速と多孔質媒体を構成するガラスビーズ, あるいは砂岩粒子の径の関数になっているのがわかる。 ここで, (12)式に代わる粘弾性流体の多孔質媒体内流動 現象を表す係数として, 次のような拡散係数を導入する。

$$
D_{f}^{\prime}=\frac{K^{\prime}}{\phi \mu^{\prime} C_{t}}
$$

従って，(10）式の圧縮率と（16）式の易動度を用いて, （11）式の拡散方程式を解くことによって，粘弾性流体 の多孔質媒体内流動の非定常圧力挙動を計算することが できる。

\section{4. 多孔質媒体内流動に関するレイノズル数 とデボラ数}

ポリマー水溶液流動の流動媒体毎の違いを比較する場 合に基準となるのは，ポリマー水溶液に加えられている 応力であり，流速の対比である。この流速を表すのに一 般的に使われているのは, 慣性力之粘性力の比を無次元 数として定義したレイノルズ数である。多孔質媒体内流 動に関するレイノルズ数は次式で定義する。

$$
R e=\frac{d U_{D} \rho}{\mu(1-\phi)}
$$

この式を岩石コアに適用する時に問題となるのは，多 孔質媒体としての岩石を構成する砂岩粒子の平均直径 $d$ の値の求め方である。実験に用いた砂岩コアと同様のべ レア仯岩を砕いて電子顕微鏡を用いて仯岩粒子径を測定 すると，Fig. 3 のように得られる。

多孔質媒体内流動において，流体の流動抵抗を評価す る場合の定量化のために使われる值としては，抵抗係数 (Resistance Factor) が测定されている。か゚りマー水 溶液の抵抗係数は, 同じ岩石コアを用いて水だけを流し た時の流動抵抗とポリマー水溶液を流した時の流動抵抗 の比として定義される。実験ではこの抵抗係数を，それ ぞれの流体について岩石コアの出入口間で測定される圧 力差を流量で割った値の比から次の上うに求める。

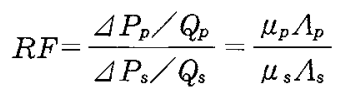

ここで, $\Lambda_{s}, \Lambda_{p}$ はそれぞれ溶媒，ポリマ一水溶液の抵 抗定数 (Resistance Coefficient) 表す ${ }^{2), 3) 。 ~}$ 

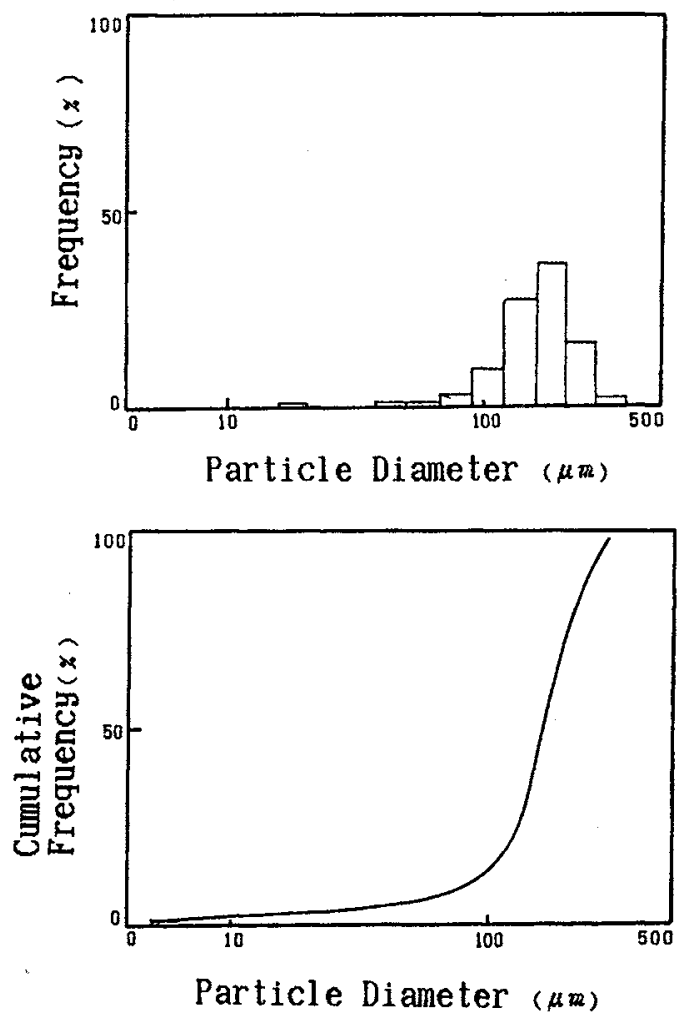

Fig. 3 Particle size distribution of Berea sandstone core.

（19）式に使われる抵抗定数 $\Lambda$ は，粘性流体の示す摩 擦係数とレイノルズ数の積として次の式で定義される。

$$
\begin{aligned}
\Lambda & =f \cdot R e \\
& =\frac{d^{2}}{\mu U_{D}} \frac{\phi^{3}}{(1-\phi)^{2}} \frac{\Delta P}{L}
\end{aligned}
$$

この式に使われる摩擦係数 $f$ は, パイプ内流動の摩擦係 数に習って次の式で定義されるるのである。

$$
f=\frac{d}{\rho U_{D}^{2}} \frac{\phi^{3}}{1-\phi} \frac{\Delta P}{L}
$$

さらに，(20) 式の抵抗定数にダルシーの式を適用する 之，抵抗定数は流体の種類に関係なく多孔質媒体の性質 のみを表す次のような簡単な式に行きつく。

$$
\Lambda=\frac{d^{2}}{K} \frac{\phi}{(1-\phi)}
$$

即ち, 抵抗定数は岩石コアの粒子径, 浸透率，および孔 隙率によって決まる定数となる。従って，（20）式〜 (22) 式が成り立つ系に扣いては，抵抗定数は流体に関わら ず一定になり，(19）式の抵抗係数（RF）に使われる $\Lambda_{p} / \Lambda_{s}$ は常に 1 になるため，測定された抵抗係数はポ リマー水溶液之溶媒の粘度の比 $\mu_{p} / \mu_{\mathrm{s}}$ を表しているこ とになる。
さらに，(22）式に多孔質媒体の浸透率之孔隙率の関 係を表す Blake-Kozeny, Carman-Kozeny 等の経験 式を適用すると，層流域では抵抗定数はいつも一定の值 をとることが示される。

$$
\Lambda=150 \sim 180 \quad(\operatorname{Re}<10)
$$

抵抗定数の幅は, Kozeny 係数を $4 \sim 5$ の範囲に取る場 合に対応して変化している。

Table 1(b) に示す三種類のサイズの違うガラスビー ズを詰めた毛細管について得られている測定值から， （22）式を用いて抵抗定数を求めてみると，141 172 と なる。一方，ビーズ径から Kozeny 係数を $25 / 6$ として Blake-Kozeny の式を用いて求めた浸透率を使うとこ の值は常に 150 と一定になる。この実測俌のばらつきは, 塩水を流して測定した浸透率がビーズ径の分布などが 原因となって Blake-Kozeny の関係から得られる浸透 率と異なるせいである。さらに，ガラスビーズを詰めた 毛細管を用いた実験による測定值から（20）式を用いて 求めた抵抗定数を，レイノルズ数に対してプロットした 結果を Fig. 4 亿示す。この塩水を流して求めたニュー トン流体としての関係と同様に, ガラスビーズを詰めた 毛細管内をポリマー試料 MS 7812 で作った $1000 \mathrm{ppm}$ 濃度のポリマー水溶液を流した場合の抵抗定数とレイ， ルズ数の関係を測定した結果す Fig. 4 にプロットした。 ガラスビーズのサイズが $600 \mu \mathrm{m}, 300 \mu \mathrm{m}$ と大きい場 合には，(19）式の抵抗係数を構成する $\Lambda_{p} / \Lambda_{s}$ の值が 1 になる関係はあるレイノルズ数の範囲内では確保されて いる。一方, ガラスビーズの径が $87 \mu \mathrm{m}$ の場合では, 測定されたレイノルズ数の範囲内では，あはやこの関係 が成り立つ部分はなく， $\Lambda_{p} / \Lambda_{s}$ の值が 1 になる関係が 成り立たないことが理解できる。ポリマー水溶液のよう な粘弾性流体の振動流による圧力損失への影響は, 多孔 質媒体を構成する岩石粒子のサイズが小さいはどはっき りと現れることを示している。

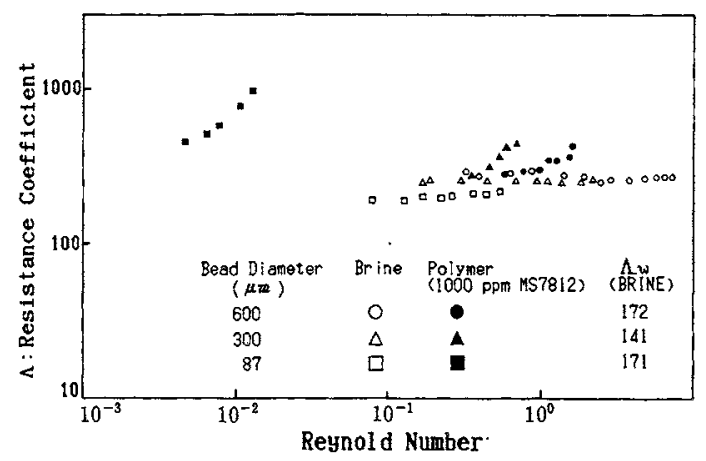

Fig. 4 Resistance coefficient of flow through glass beads packed capillary tube. 


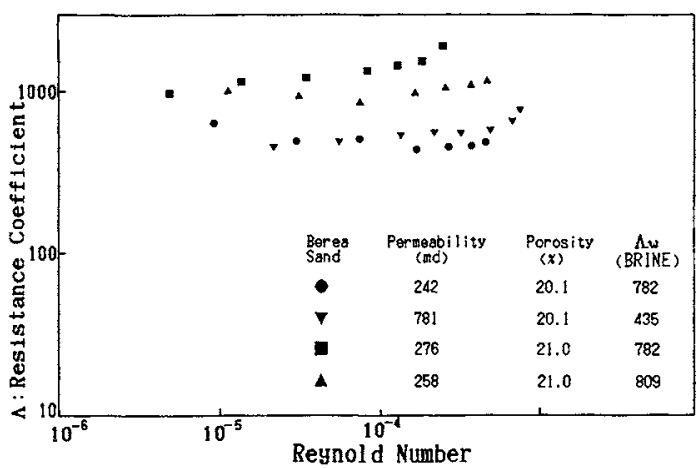

Fig. 5 Resistance coefficient of flow through Berea sandstone.

ガラスビーズを詰めた毛細管を用いて行ったと同様の 実験をべレア砂岩コアを用いて行った結果についてす Fig. 5 にプロットしてみた。ここで, Fig. 3 で求めた ベレア砂岩の平均粒子径を用いて（22）式により計算し た抵抗定数は 210７08となり，(23）式で与えた值より かなり大きくなっている。ベレア砂岩のような岩石コア では Blake-Kozeny の関係が成り立たなくなっている ためこのような大きな差が表れてくることになるが， レイノルズ数や抵抗定数の計算に用いる岩石粒子径の求 め方が難しくなっていることを示している。また, ベレ ア砂岩では，ポリマー分子の吸着による水力半径の変化 や浸透率の低下による効果す問題となる。なお，Fig. 5 では, 岩石コア内に塩水を流した場合の抵抗定数はひ とつの流速についてしか測定していないため，図中右下 にその值を示してある。ポリマー水溶液を流して测定 した抵抗定数との関係からはばらつきはあるあのの $\Lambda_{p} / \Lambda_{s}$ の值が一定になるレイノルズ数の範囲が示され ているようにみえる。しかし，岩石コア内流動について は, 正確に測定されていないパラメーターが多くなり, これまで述べた理論式がガラスビーズを詰めた毛細管内 の流動について行ったようにうまく適用できないことが わかる。

以上は, 通常の粘性流体の多孔質媒体内流動を対象 としたレイノルズ数についての説明であるが, 多孔質 媒体内を流れる振動流の結果として現れるダイラント 流体としての挙動を調べるのに便利な指標として、レ イノルズ数と同様の無次元数として,デボラ数がある。 デボラ数は, ポリマー粒子の粘弾性を表す緩和時間 $\lambda$ と伸び速度 $\varepsilon$ を掛けたものとして, 次式で定義され る。

$$
D e=\lambda \cdot \varepsilon
$$

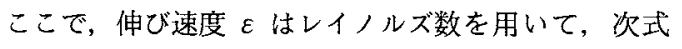
で評価する。

$$
\begin{aligned}
\varepsilon & =\frac{\beta U_{D}}{d} \\
& =\frac{\beta(1-\phi) \mu R e}{\rho d^{2}}
\end{aligned}
$$

定数 $\beta$ は多孔質媒体を構成する粒子のパッキング状態を 示すパラメーターで, 球が正方格子状に充填されている 場合には $\beta=1.7$, あるいは最密充填されているょうな 場合には， $\beta=6.3$ となる值である。ガラスビーズのよ うな同じサイズを持つ完全球体のパッキングでは, それ ぞれの充填方法毎に孔隙率 $\phi$ あ $47.6 \%$ あるいは $25.9 \%$ と与えられる

ここで (25) 式で評価される伸び速度は, 多孔質媒体 内のスロートと孔腺空間の間を一つのサイクルとして考 える密度变化距離をポりマー水溶液が通過する時間の逆 数を意味する。これは，(7)式で表される振動角速度と 同じあのを表している。このため, デボラ数はこの圧縮， 膨脹サイクルの周期時間 $\tau$ と緩和時間 $\lambda$ の比を表してお り, 前節で述べた $\omega \lambda$ と同じように, この圧縮, 膨脹サ イクルの周期が緩和時間に比べて充分に長い場合, 即方 デボラ数が小さい間は，ポリマー水溶液はスロートと孔 隙空間の流路径に従って密度变化を対応させるのに充分 な時間を与えられるため, 流動に抗する圧力損失は壁と の摩擦による粘性損失だけになる。逆にこの周期時間 が緩和時間に比べて短い場合は, 流動方向における垂直 応力変化に伴う密度変化の対応に充分な時間が与えられ ず, 次の圧縮, 膨脹サイクルに移っていくため, その間 に極低密度状態が発生し, 粘性損失の他に弾性エネルギー 損失を伴い，非常に大きな圧力損失が測定されることに なる。また, この場合, 同時に見られる現象として, こ の応力緩和が充分に行われないために, 流動状態は常に 非定常な変化内に置かれることになり, 多孔質媒体が長 ければ長い程, 非常に長い間非定常の圧力上昇を続ける 現象が観察されることになる。

デボラ数が意味しているのは，これまでに述べてきた， 振動によってポリマー水溶液にかかる压力変化による流 動抵抗之摩擦抵抗を起こす粘性抵抗の比であり, 流動に よって生ずる圧力損失が，この二っの効果によってどの 割合で分担されるのかの比率を表すことになる。即ち, デボラ数が大きくなればなるはど, 振動による弾性エネ ルギー損失が粘性抵抗を上回ることを意味する。垂直応 力とせん断応力の間の相関関係は，これらの二つの応力 の比をとって次のように与えられているい。

$$
\frac{\sigma_{x x}-\sigma_{r r}}{\sigma_{x r}}=2 \lambda \gamma
$$

ここで, $\sigma_{x x}$ と $\sigma_{r r}$ はぞぞれ $x$ 方向 (流れの方向), お よびそれと直交する方向での垂直応力を表し， $\sigma_{x r}$ は 


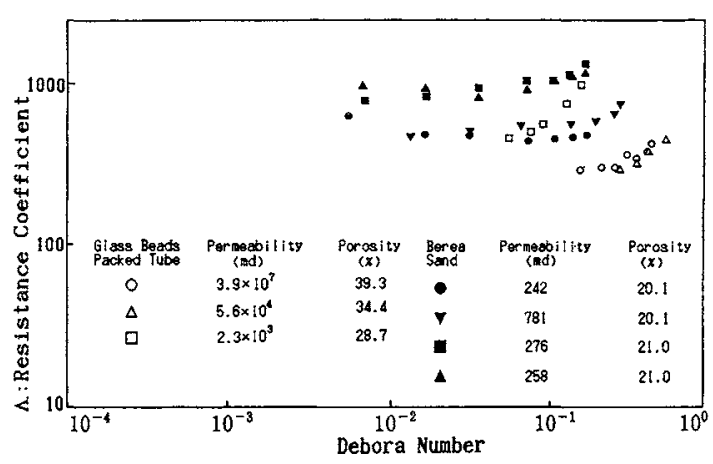

Fig. 6 Resistance coefficient of flow through porous media.

$x$ 方向でのせん断応力を表す。

ずり速度 $\gamma$ として GOGARTY ${ }^{5)}$ の提唱した式を用い ると，(26）式の右辺は次のようになる。

$$
2 \lambda \gamma=\frac{12 \sqrt{25 / 3}}{\beta} \frac{3 n+1}{4 n} \frac{1-\phi}{\phi^{2}} D e
$$

(27) 式によって，この二つの応力の比が, 先に (24) 式で定義したデボラ数で与えられることが分かる。この 比が 1 になる点が，垂直応力とせん断応力が等しくなる 流速で，ずり速度がこの值を越えると垂直応力による弾 性エネルギー損失の方が，せん断応力による圧力損失よ り重要になってくる。この限界ずり速度は $\gamma=1 / 2 \lambda$ と 表され，(27）式に $n=0.654, \beta=6.3, \phi=0.259$ を与 えるとデボラ数 $D e=1.9 \times 10^{-2}$ が得られダイラタント 流動が卓越する流速域は， $D e>2 \times 10^{-2}$ の範囲として 与えられることになる。

Fig. 4, Fig. 5 における抵抗定数の測定值をレイノ ルズ数の代わりにデボラ数を用いてプロットし直すと Fig. 60ような関係が得られる。ここでは，デボラ数 の計算に当たって，前報1で求めた緩和時間 $\lambda$ の值を与 えている。デボラ数の採用によって，抵抗定数が上昇に 転ずる点がガラスビーズを詰めた毛細管，あるいは岩石 コアの場合についてむ同じようなデボラ数の範囲に集まっ てくる様子がみられる。

\section{5. 抵抗係数}

次に既に第 3 節で述べた，粘弾性流体の多孔質媒体内 流動を表す拡散方程式 (11) 式を解いて，解析的に抵抗 係数を求めることを試みる。（11）式に使われている拡 散定数 $D_{f}$ を新しく定義した振動流についての(10) 式 の複合圧縮率 $C_{t}$ と（16)式の易動度 $K^{\prime} / \mu^{\prime}$ を用いて表 す之，(11）式は非線型方程式となるため解析的に解く ことができない。そこで，第一段階として，拡散係数

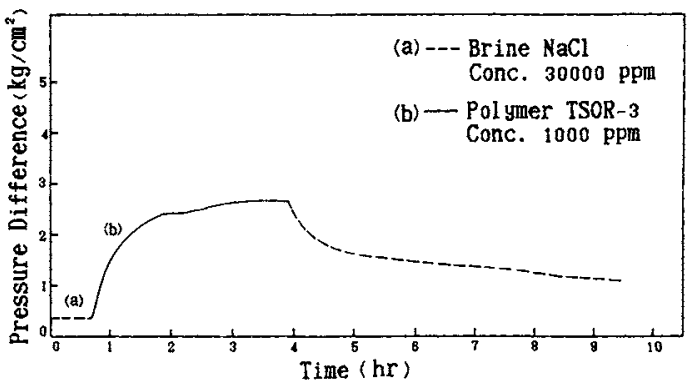

Fig. 7 Pressure history record during polymer injection test. (Core No: TSOR-3-30 Na).

$D_{f}$ を固定して (11) 式を解いてから，その解析解に (10) 式と（16）式を適用して多孔質媒体内流動の実测值と比 較する手法をとる。

ここで，(11）式右辺の係数となっている拡散定数を 構成するパラメータのうち， $\phi / K$ は多孔質媒体の性状 を表す定数であり，いずれの流体についてあ共通である。 残りの $\mu C$ は流体の性状を表す定数であり，（1）式より $\mu_{0} C_{t}=\alpha \lambda$ となる。つまり，（11）式によって表される 圧力の拡散現象には，ポリマ一皮溶液の持つ粘弾性効果 が含まれることになる。Fig.7は，ポリマー水溶液を 岩石コア内へ流した場合のコア雨端差圧の測定記録を 示す。図中の (a) 加 (b)八変わる点に扔いて, 塩 水からポリマー水溶液八圧入流体が切り換えられてい る。この（b）の領域にみられる差圧の過渡応答現象 は, 拡散係数のパラメータ $\alpha \lambda$ の表す緩和時間によっ て支配されていると考えられる。Fig.7の（a）の塩 水だけを流した部分でみられるように，この奏験に用 いたコアは直径が $2.435 \mathrm{~cm}$ ，長さが $6.923 \mathrm{~cm}$ で孔隙率 18.9\%と小さな孔隙容積しか白たないため，压入を 開始すると瞬時に一定の差压に達するのが普通であ る。Fig. 7 の（b）にみられるような同じ容積の流体が 2〜3時間に渡って圧力過渡応答をする現象はポリマー 水溶液のような粘弾性流体だけに極めて特徴的な現象 として捕らえられる。この現象は，ポリマー水溶液の 持つ動的压蓿率 $C_{i}$ の大きさによって与えられるパラ メーター $\mu_{0} C_{t}$ の働きとして表されることになる。つま り，掂散係数 $D_{f}$ を小さくしたことにより，压力变化の 搪散が小さくなり圧力が伝幡し難くなったことを意味す 万。

(11) 式をガラスビーズを詰めた毛細管や岩石コアを 用いた流動実験を行っている条件を初期条件，境界条件 として与えてフーリエ変換を用いて解析的に解くと堕力 変化として次式が得られる。 


$$
\begin{aligned}
P(x, t)= & \frac{2 \mu Q L}{\pi^{2} K A} \sum_{n-1}^{\infty} \frac{\left\{1+(-1)^{n+1}\right\}}{n^{2}} \\
& \times\left\{1-\exp \left(-\frac{n^{2} \pi^{2} t}{D_{f} L^{2}}\right)\right\} \\
& \times\left\{\cos \left(\frac{n \pi x}{L}\right)-\cos \left(\frac{n \pi}{2}\right)\right\}
\end{aligned}
$$

この解を用いてガラスビーズを詰めた毛細管，あるいは 岩石コアの入口と出口の艮力差の時間变化を求めると次 式が得られる。

$$
\begin{aligned}
\Delta P= & \frac{2 \mu Q L}{\pi^{2} K A} \sum_{n-1}^{\infty} \frac{\left\{1+(-1)^{n+1}\right\}}{n^{2}} \\
& \times\left\{1-\exp \left(-\frac{n^{2} \pi^{2} t}{D_{f} L^{2}}\right)\right\} \\
& \times\{1-\cos (n \pi)\}
\end{aligned}
$$

こうして得られた圧力差を実験で測定したガラスビー ズを詰めた毛細管や岩石コア雨端の間の厈力差と比較す るために, 拡散係数 $D_{f}$ の值として, 粘弾性流体につい て (17) 式から得られる新たな拡散係数 $D_{f}^{\prime}$ を適用する。 ポリマー水溶液のような粘弾性流体の振動流については, 既にFig. 2 でみてきた通り，流速が大きくなり角振動 数 $\omega$ が大きくなっていくと，この拡散係数 $D_{f}^{\prime}$ は小さ くなる。つまり，この圧力変化の過渡応答時間が大きく なって非定常状態が長く続くことがわかる。これは，小 さな径を持つガラスビーズを詰めた毛細管や岩石コア内 をポリマー水溶液を流す実験で得られる入口，出口間の 差圧変化が長い時間定常值に達しない事実を良く説明し ている。

さらに，(29）式の非定常流状態から時間が充分経っ $\tau(t=\infty)$ 定常状態に達した場合の圧力差は次式で与 えられる。

$$
\Delta P(t=\infty)=\frac{\mu Q L}{K A}
$$

この定常状態での圧力差 /流量 $\Delta P(t=\infty) / Q$ を用 いると，(19) 式の抵抗係数は次のようになる。

$$
\begin{aligned}
R F & =\frac{\left(\frac{\mu^{\prime}}{K^{\prime}}\right)_{p}}{\left(\frac{\mu}{K}\right)_{s}} \\
& =\frac{\mu_{p}}{\mu_{s}}-\frac{K}{\mu} \frac{4 \rho q}{\pi d^{3}} \frac{\partial d}{\partial x}
\end{aligned}
$$

これによって，第 4 節で議論してきたように，抵抗係 数はデボラ数が $10^{-2} \sim 10^{-1}$ となるような流速範囲内で は，(31）式右辺第一項だけで表されるようにポリマー 水溶液と溶媒自身の粘度の比になっているが，それより 流速が大きくなる部分では (31) 式右辺第二項が働き始 めることになってこの関係から離れていくことが定量的
にも裏付けられる。

\section{6. 実測値とのマッチング}

前節までに得られた理論計算式を，ポリマー氷溶液を ガラスビーズを詰めた毛細管内，およびベレア砂岩コア 内を流して行った実験の結果に適用してその妥当性を検 馀した。

実験に使われたガラスビーズの大きさ，毛細管，岩石 コアの直径，長さ等の諸元は Table 1 に整理した通り である。岩石コアの粒子径は，流動実験に使ったものと 同種類のベレア砂岩を砕いて電子顕微鏡で観察, 测定し た粒子径分布の最頻值とした。

粒子径 $87 \mu \mathrm{m}$ のガラスビーズを詰めた毛細管による ポリマー水溶液流動実験の測定結果を Fig. 8 に破線で 示す。この実験に用いた溶液は,ポりマー試料 MS 7812 の $1000 \mathrm{ppm}$ 水溶液である。この実験結果から, 流速が 大きくなっていく場合に，振動流の効果によって急激に 差圧が加速度的に堌加していく様子が分加る。この差圧 の増加傾向は粘度変化だけではうまく説明できない。こ の測定例では，圧入流速を $0.00053 ， 0.00061 ， 0.00088$ ， $0.00109 \mathrm{cc} / \mathrm{s}$ と 4 段階に変化させている。この場合, 定常状態での差圧は各々, $0.82,1.06,2.07,3.28 \mathrm{Kg} /$ $\mathrm{cm}^{2}$ と変化しており，これを粘度変化だけで表そうと すると，各流速に対して粘度が $7.5,9.0,12,15 \mathrm{mPa} ・ \mathrm{~s}$ と増加したかのように計算される。一方，本論文で提案 した方法で，(29）式を用いて計算を行うと，図中に○ でプロットしたように，実験值の傾向をうまくとらえる ことができる。この計算結果は，易動度の変化を与える （16）式で, 流路の断面積変化の勾配を表す $\partial d / \partial x$ を マッチング・パラメータとしてうまく与えることによっ て得られる。このことから，ポリマー水溶液の弾性効果 による圧力損失を考慮することによって，粘性抵抗は流 速の増加によって低下する傾向を残したままです，流速 の増加に伴うダイラタント流動の圧力損失を計算できる ことがわかる。即ち，孔隙流路が激しく変化するような 多孔質媒体については， $\partial d / \partial x$ の值が極めて大きくな る系として扱うことによって易動度の減少を表すことが できる。

Fig. 8の測定差圧のマッチングにおいて，流速の増 加による易動度の減少の他に，もうひとつの重要な点は， 各流速変化の度に現れる長い非定常の過渡応答部分の計 算である。こちらの現象は，(10）式で表される複合王 縮率の導入によって，ポリマ一水溶液の示す見掛け压縮 率が流速毎に変わることから得られる。マッチングした ケースの压縮率の值をみると，溶媒だけを流した場合は $4.5 \times 10^{-10} \mathrm{~Pa}^{-1}\left(4.5 \times 10^{-5} \mathrm{~atm}^{-1}\right)$ と一定である。一方, 
ポリマー水溶液を流した場合は, 流速変化に従って $9 \times$ $10^{-5} \mathrm{~Pa}^{-1}\left(9 \mathrm{~atm}^{-1}\right) \sim 2.8 \times 10^{-4} \mathrm{~Pa}^{-1}\left(28 \mathrm{~atm}^{-1}\right)$ と変化 しており，両ケースに使われた静的圧縮率と動的圧縮率 のはっきりした差異を示している。ポリマー水溶液のよ うな粘弾性流体の流動系においては，前報】で導入した 緩和時間から得られる動的圧縮率が大きく働いているこ とが分かる。この動的压縮率の導入によって，ポリマー 水溶液を多孔質媒体内を流した場合に観測されるような 極めて長い過渡応答時間の存在がうまく説明される。

Fig. 8 には，同じ毛細管に塩水だけを流した場合の 测定值について子(29) 式によって求めて比較してい る。当然のことながら塩水だけの流動の場合, BlakeKozeny の関係から得られる浸透率を用いて, 流量变化 に伴う差压変化が充分再現できることが分かる。勿論, 実測においてあ，計算においても殆ど瞬時に差压は定常 状態に達している。このため, 図中には，塩水だけを流 した場合に計算される差圧については定常值を一点だけ プロットして示している。計算と実测による差圧が多少 ずれているのは, Blake-Kozeny の関係から求めた浸 透率之実測の差圧から求めた浸透率が少しずれているこ

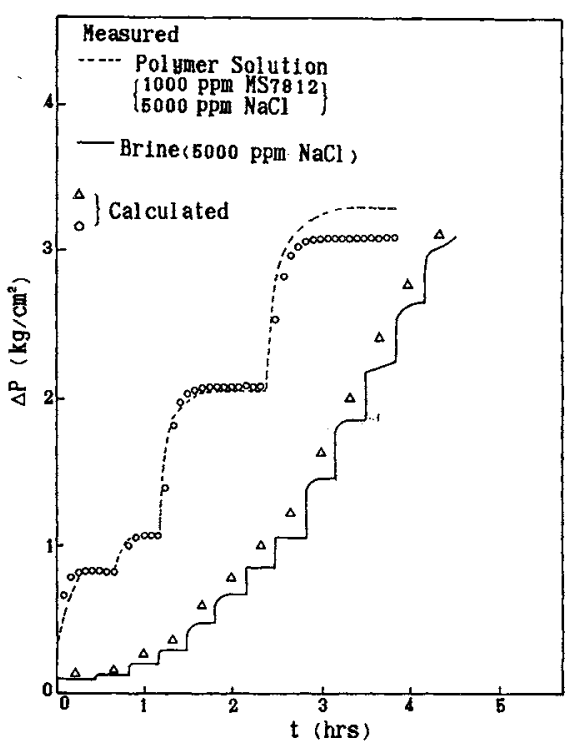

Fig. 8 Matching of pressure difference between inlet and outlet of capillary tube packed with 290 mesh glass beads.

Table 1 Properties of polymer solution and dimensions of capillary tube models and cores.

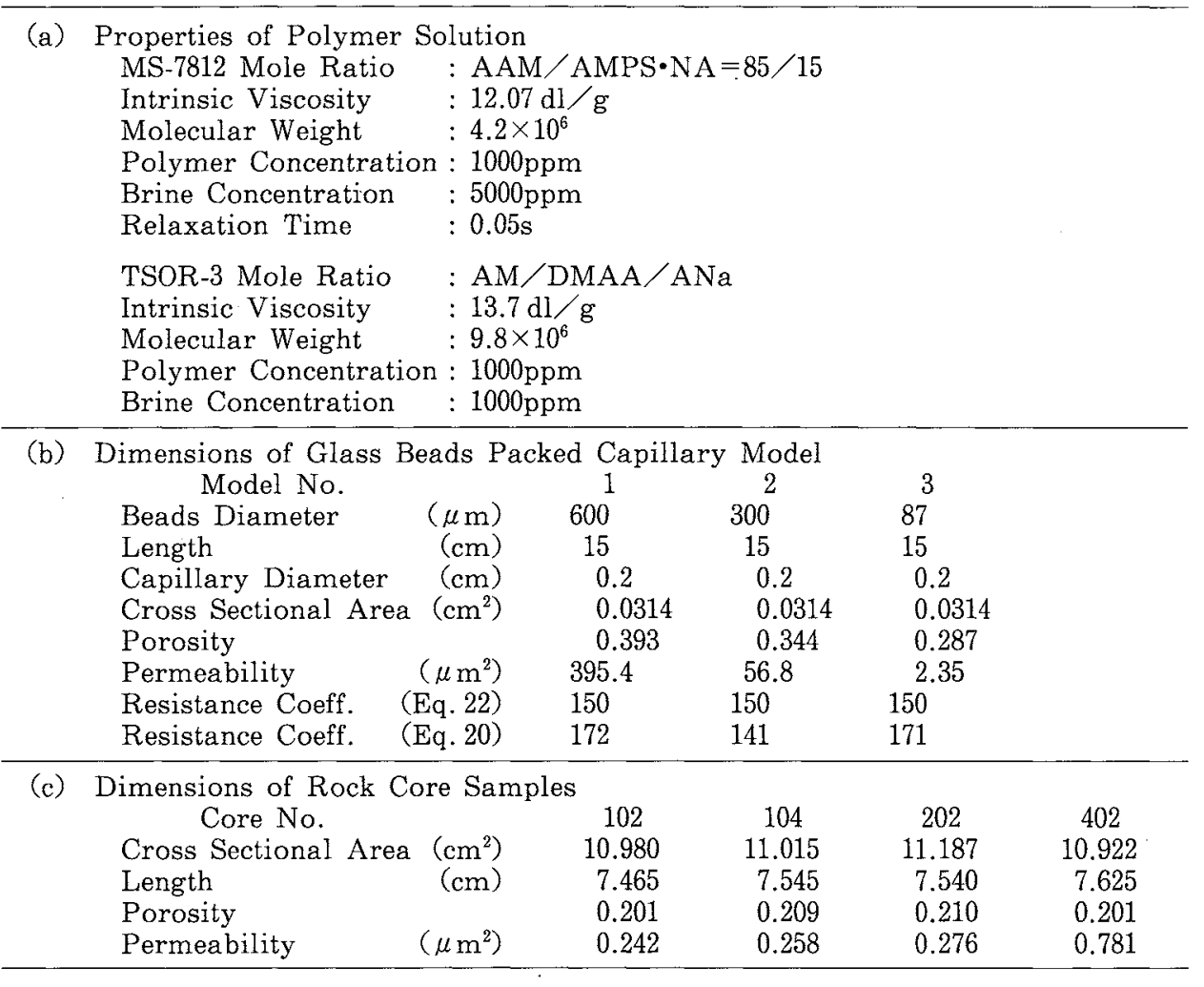




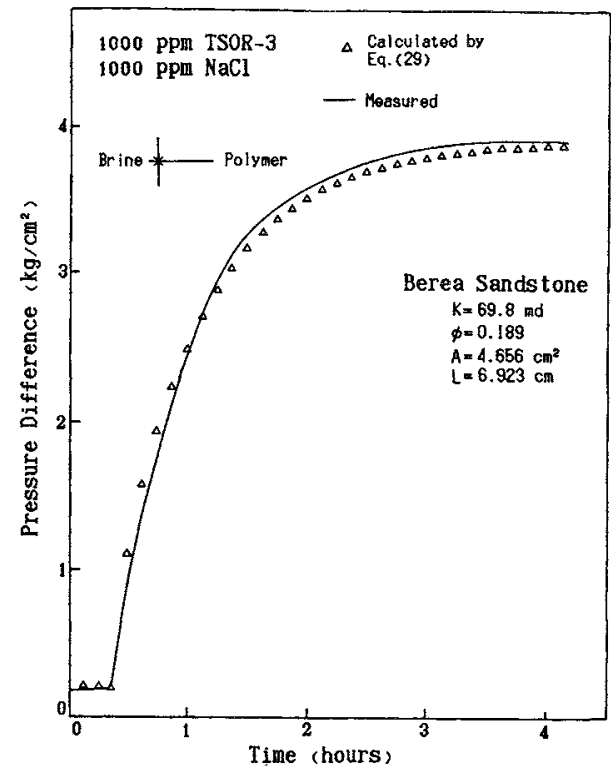

Fig. 9 Matching of pressure difference between inlet and outlet of Berea sandstone core.

とが原因になっている。

次に，ポマー試料 TSOR-3 $\mathrm{NaCl}$ 濃度 $1000 \mathrm{ppm}$ の塩水に溶加して作成した $1000 \mathrm{ppm}$ 濃度のポリマー水 溶液をべレア砂岩コアに通した時に测定された差压変化 の計算例をFig. 9 に示す。図中には，実験結果が実線

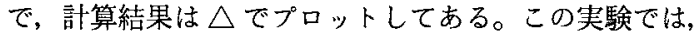
先ず溶媒としての塩水を $0.00326 \mathrm{cc} / \mathrm{s}$ の流速で流して 浸透率を求めた後, $0.00263 \mathrm{cc} / \mathrm{s}$ の流速でポリマー水 溶液を流して差圧を測定している。この一定流速の測定 からだけでも，ポリマー水溶液がベレア眇岩内を流動す る時には, 予め測定されているポリマー水溶液の粘度だ けからでは予想されない大きな差圧と長い非定常時間が 観察されることがわかる。この実験流速におけるポリマー 水溶液の粘度は $13 \mathrm{mPa} \mathrm{s}$ である。Fig. 9 に示したよ うな差王を計算するためにはこの 5 倍以上の粘度が必要 となる。この流動抵抗も岩石コア内での振動流による弾 性エネルギー損失によるもの上考えると，粘度を变えな くてい（16）式による易動度の減少によってうまく計算 される。また，このマッチング計算では，岩石コアのれ 隙流路の変化勾配の值は極めて大きくとる必要があり, このような岩石コア内流動での振動流が極めて大きい角 速度で変化していることを暗示している。岩石粒子の平 均径加予想される流路よりも，より複雑に入り組んだ 流路変化があることが予想される。このような変化の激 しい流動径路を持つ岩石コア内流動では，非常に長い非
定常時間が特徴よなって観測される。Fig.9に示され る3時間に毛及ぶ圧力の過渡応答時間は，ポリマー皮溶 液に $3 \times 10^{-4} \mathrm{~Pa}^{-1}\left(3 \mathrm{~atm}^{-1}\right)$ という複合圧縮率を与えて 搪散時間を伸ばすことによって計算されている。但し， ここで岩石コアの場合は，ポリマー分子の拡散や岩石粒 子表面への吸着等による浸透率の低下等, 他の原因が働 いていることもわかっているため, 必ずしる振動流だけ が原因でこの効果が現れていると考えるのは少し無理が あることを注意しておく必要がある。

\section{6. 結 言}

本研究は，ポリマー水溶液に代表される粘弾性流体を， 油層のような多孔質媒体内に注入する時にみられる異常 な圧力上昇の原因を考察するために，その流動抵抗の定 量的な評価を試みたあのである。これまで，圧入流体と して使われてきた水のような非生縮性流体と違って，ポ リマー水溶液のような粘弾性流体を用いる場合に，新た に考虑に入れなければならない粘弾性流体の振動流につ いて次のような新しい知見が得られた。

(1) ポリマー水溶液の多孔質媒体流動においては, 弾 性流体が孔隙空間亡，孔隙空間を結ぶスロート部分 とを交互に流れるために，流速の大小を繰り返す振 動流が起こる。粘弾性流体の振動流におりる弾性工 ネルギー損失は, 粘弾性流体に特有の応力緩和現象 之関係している。多孔質媒体内に扔ける流路断面積 の変化に伴う流速振動に対応する流体の密度変化が 繰り返される。弾性の大きな流体が密度振動して流 れ，ある振動数を越えると弾性エネルギーの損失が 起こり，粘性による摩擦損失以外の圧力損失を受け る。この弾性エネルギー損失に影響する緩和時間を 決める流体の性質は粘度と圧縮率であり，特に压縮 率の中です従来測定されていない動的圧縮率の存在 は, ポリマー水溶液のような粘弾性流体では今後注 目されるべき流体特性と考えられる。

(2) ポリマー水溶液のような粘弾性流体の多孔質媒体 内流動を表す運動方程式として，ダルシーの式とオ イラーの式を同時に満たす（15）式を提案した。ま た, 粘弾性流体の非定常流動挙動は, 粘性の他に弾 性効果も満たすような拡散方程式の解である必要が あるため，拡散方程式にこの運動方程式を適用して 得られる解を用いて解析した。

（3）粘弾性流体の多孔質媒体内流動において，粘性に よる摩擦損失の効果は流速に比例して起こり, 振動 による弾性エネルギーの損失は流速の 2 乗に比例し て起こるため，流速が小さい間は，粘性が主な圧力 損失の原因となり，流速が大きい範囲では振動が主 
な圧力損失の原因となる。このふたつの効果の入れ 代わる流速は, 垂直応力とせん断応力の比として定 義されるデボラ数によって判断される。振動流によ る垂直応力の勃果はデボラ数が $10^{-2} \sim 10^{-1}$ を越え るときに卓越し始める。

（4）ポリマー水溶液のような粘弾性流体を岩石コアの ような多孔質媒体内を流すとき，粘度による摩擦損 失の他に，振動流による弾性エネルギー損失が起こ り，圧力損失は流速の増大に伴って加速度的に増大 する。この現象は, 圧入坑井の近傍のように流速の大 きい部分で極めて重要な役割を果たすと考えられる。 本論文では, 粘弾性流体の多孔質媒体内流動時の非定 常流動を定量的に解析することを試みたが，この分野の 定量的解析は末だその端緒についたばかりであると言え る。このため, 今後さらに粘弾性流体特有の流体性状を 実測する方法論む含めて，岩石コアを用いた流動実験を 繰り返して, 本解析法の妥当性を検証していく必要があ る。同様の解析は，ポリマー水溶液に対してだけでなく， 今後，回収技術の中心となる EOR に係わる流体にも広 く適用されるものだけに，さらに広く研究されていくこ とを期待する。

\section{謝 辞}

本研究を行うに当たって，研究協力を頂いた石油公団 石油開発技術センター, 並びに住友石油開発株式会社に 対し, 深く感謝します。本研究の実験, 報告書作成を通 じ研究協力を頂いた早稲田大学理工学部研究科陳俩明君 に深く感謝します。

\section{記号の説明}

$A$ : 毛細管, あるいは岩石コアの断面積, $\mathrm{m}^{2}$

$C$ : 静的圧縮率, $\mathrm{Pa}^{-1}$

$C_{i} \quad$ : 動的圧縮率，あるいは時間圧縮率， $\mathrm{Pa}^{-1}$

$C_{t}$ : 複合圧縮膟, $\mathrm{Pa}^{-1}$

$D_{f}$ : 僅少圧縮性流体の拡散係数, $\mathrm{m}^{2} / \mathrm{s}$

$D_{f}^{\prime}$ : 粘弾性流体の拡散係数, $\mathrm{m}^{2} / \mathrm{s}$

$d$ : ガラスビース, あるいは秒岩粒子の直径, $\mathrm{m}$

$f$ : 摩擦係数

$K$ : 浸透率, $\mathrm{m}^{2}$

$K / \mu:$ 粘性流のみの流動係数, $\mathrm{m}^{2} / \mathrm{Pa} / \mathrm{s}$

$K^{\prime} / \mu^{\prime}$ : 粘性流, 振動流を含む流動係数, $\mathrm{m}^{2} / \mathrm{Pa} / \mathrm{s}$

$L$ : 毛細管, あるいは岩石コアの長さ, $\mathrm{m}$

$n$ : : レオロジー方程式の指数

$P$ : 圧力, $\mathrm{Pa}$

$\triangle P$ : 差压, $\mathrm{Pa}$

$\triangle P(t=\infty):$ 定常状態での入口, 出口間の差压, $\mathrm{Pa}$

$q$ : 孔隙空間流路を流れる流量, $\mathrm{m}^{3} / \mathrm{s}$
Q : 毛細管，あるいは岩石コアを流れる流量, $\mathrm{m}^{3} / \mathrm{s}$

$R e$ : レイノルズ数

$R F$ : 抵抗係数 (Resistance Factor)

$r$ : ガラスビーズ，あるいは砂岩粒子の半径, $m$

$S$ : 孔隙空間流路の断面積, $\mathrm{m}^{2}$

$t \quad:$ 時間, $\mathrm{s}$

$U:$ : 流路内の平均流速, $\mathrm{m} / \mathrm{s}$

$U_{D}:$ ダルシー流速, $\mathrm{m} / \mathrm{s}$

$V$ : 弾性波の速度, $\mathrm{m} / \mathrm{s}$

$x$ : 距離, $\mathrm{m}$

$\alpha \quad:$ 剛性率と圧縮率の関係を示す比例定数

$\beta \quad:$ パッキング定数

$\gamma$ :ずり速度, $\mathrm{s}^{-1}$

$\varepsilon$ : 伸び速度, $\mathrm{m} / \mathrm{s}$

$\Lambda$ : 抵抗定数 (Resistance Coefficient)

$\lambda \quad:$ 緩和時間, $\mathrm{s}$

$\mu \quad:$ 流体の粘度, $\mathrm{Pa} . \mathrm{s}$

$\mu_{0}$ ：ポリマー水溶液のゼロシェア粘度，Pa． $\mathrm{s}$

$\rho:$ : 流体の密度, $\mathrm{Kg} / \mathrm{m}^{2}$

$\rho_{0} \quad$ : 基準圧力における流体密度, $\mathrm{Kg} / \mathrm{m}^{3}$

$\sigma_{x x}:$ 流動方向での垂直応力, $\mathrm{Pa}$

$\sigma_{r r}$ : 流動方向と直交する方向での垂直応力, $\mathrm{Pa}$

$\sigma_{x r}:$ 流動方向でのせん断応力, $\mathrm{Pa}$

$\tau:$ 振動流の周期, $\mathrm{s}$

$\phi:$ 孔隙率

$\omega$ : 振動流の角速度, $\mathrm{rad} / \mathrm{s}$

添 字

$p \quad:$ ポリーー水溶液

$s \quad$ : 溶媒

\section{参 考 文 献}

1）田中舘忠夫・オマール・アブデルカリム．山崎豊彦， 1991: ポリアクリルアミド水溶液の多孔質媒体内流 動抵抗の定量的評価. 石技誌, 57(1), p. 1-10.

2) KullCKE, W.M., 1984: Flow Behavior of Dilute Polyacrylamide Solutions through Porous Media.

1. Influence of Chain Length, Concentration, and Thermodynamic Quality of Solvent. Ind. Eng. Chem. Fundam., 23.

3) LIM, T., UHL, J.T. and PRUD'HOMME, R.K., 1986: The Interpretation of Screen-Factor Measurements. SPE Reservoir Engineering, May.

4) DAUBEN, D.L. and MENSIE, D.E., 1967: Flow of Polymer Solutions Through Porous Media. JPT, August.

5) Gogarty, W.B., LeVy, G.L. and FoX, V.G., 1975: Viscoelastic Effects in Polymer Flooding through Porous Media. SPE Paper 4025. 